\title{
Inflation, Unemployment and NAIRU Estimate in Indonesia: Phillips Curve Approach
}

\author{
Nurul Hafnati $^{1^{*}}$ | Sofyan Syahnur ${ }^{2}$ \\ 1 University of Syiah Kuala, Faculty of Economic and Business, Department for Economic, Banda Aceh, Aceh, Indonesia \\ 2 University of Syiah Kuala, Faculty of Economic and Business, Banda Aceh, Aceh, Indonesia
}

\begin{abstract}
The present study was carried out to analyze the relationship between inflation and unemployment in NAIRU estimate in Indonesia through Phillips curve approach during 25 years data from 1991-2016. The analysis model used in this research was Vector Error Correction Model (VECM) as attempts to determine the long run and short run relationships between inflation and unemployment matters in Indonesia. The results of Granger causality test indicated two-way relationship between inflation and unemployment in Indonesia. The formulated resultsonlong run estimate pointed out that unemployment delivered negative and significant effects on inflation. Nonetheless, Wald Test designated that there was a short run relationship between inflation and unemployment
\end{abstract}

Key words: Inflation, Unemployment, Phillips Curve, NAIRU, Vector Error Correction Model

JEL Classification: E24, E31, F41

\section{INTRODUCTION}

Inflation and unemployment are two economic mattersfacing each country in the world. The relationship between inflation rate and unemployment refers to the theory of an economist, A.W. Phillips (1958), was investigating wage inflation and unemployment in England from 1861 to 1957. Phillips discovereda consistent inverse relationship that if the unemployment rate is high, then wage will increase slowly, and if the unemployment rate is low, then wage will increase rapidly. An empirical study on inflation and unemployment rate were then developed by Samuelson and Solow (1960) who found a trade-off between inflation rate and unemployment rate in the United States. Further development on Phillips curve phenomenon was proposed by Friedman (1968) and Phelps (1968) stating that trade off between inflation rate and unemployment rate will occur only in the short run. While in the long run, it will not occur because in the long run, monetary policy makers will face a vertical Phillips curve, where the unemployment rate tends to be at its natural rate, so that the prevailing monetary policy will not only affect inflation rate.

Friedman (1968) and Phelp (1967) were the first economists to introduce the term natural employment rate or so-called non-accelerating inflation rate of unemployment (NAIRU) which is a component in the Phillips curve. NAIRU is a modern inflation theory where if the unemployment rate is low, then it is not followed by high inflation. This corresponds to the unemployment rate of sources where workers and market products are in a state of inflation balance. Inflation balance occurs when there is no excess in demand and no supply shocks. In NAIRU theory, it is explained that there is no negative relationship between inflation and unemployment, and Phillips curve in

\footnotetext{
*Corresponding Author, e-mail: nurulhafni@mhs.unsyiah.ac.id
} 
the long run is vertical. If policy makers use Phillips curve by selecting the higher inflation in order to reduce unemployment, then the reduction in the number of unemployments is not permanent. In NAIRU hypothesis, there is a condition that unemployment will eventually return to its normal and natural level, regardless of the inflation rate. NAIRU may cause 3 conditions that inflation will increase if unemployment rate is below NAIRU, inflation will decrease if unemployment rate is above NAIRU, and inflation will be stable or balance if unemployment rate is equal to NAIRU. Thus, if the government seeks to reduce unemployment below NAIRU, it will lead to increasing inflation, so that workers and companies will expect inflation to be higher. Higher inflation expectation leads to an increase in inflation expectation. Rising inflation expectation for a long time will make the economy to be slower, so that contraction in economic activity will make output to return to its original potential, and the unemployment rate returns to a reasonable level. Therefore, in NAIRU theory, the reduction of number of unemployments can be carried out without the increase in inflation by maintaining the unemployment to be equal to NAIRU. According to Helali (2018) the NAIRU model is a standard inflation model based on the anticipation of the augmented Phillips curve. In This study the time-path of the NAIRU is extracted from the information contained in the measurement equations by employing the Kalman filter recursions. As the true values of the unobserved components - including the unemployment gap and the NAIRU - are unknown, the Kalman filter provides an algorithm to finding estimates for the unobservables (Heimberger (2017)).

In Indonesia, unemployment is a problem in the economy due to its increasing number every year. In Indonesian economic development, job opportunities are the main problem because the gap in getting jobs, which is the gap between the growth of labor force and the limited job field directly leads to high unemployment rate. This research used time series data from 1991-2016 with the objective to determine the presence of Phillips curve in Indonesia. In accordance with this objective, testing is needed to analyze the relationship between inflation and unemployment in short and long runs for 25 years. In addition, it is necessary to conduct a causality test between unemployment rate and inflation rate. This research consists of 5 sections. Section 1 presents an introduction. Section 2 presents a literature review. Section 3 describes the analysis of theoretical methodology. Section 4 describes data source and methodological framework used in this research. Section 5 describes the the research results and section 6 concludes the results of this research.

\section{PREVIOUS RESEARCH}

Samuelson and Solow examined the relationship between inflation and unemployment in the United States. The result was in accordance with Phillips's showing that there was a negative relationship between inflation and unemployment and the result was the first result supporting the Phillips theory. Friedman (1968) and Phelps (1967) analysis indicated the difference between short and long run Phillips curves. As long as the average inflation rate remains constant as in 1960 's, inflation and unemployment will be inversely proportional. But if the average inflation rate changes when policy makers seek to suppress unemployment rate below the natural rate, the unemployment rate will return to its natural rate after the adjustment period. The research has finally concluded that there is no trade-off between inflation and unemployment in the long run.

The research hypothesis of Friedman (1968) and Phelps (1967) was supported by Lucas (1976) stating that there was no trade-off between inflation and unemployment in the long run. Differences of opinion about whether there is a trade-off or not make the researchers interested in conducting a research on inflation and unemployment. Alogoskoufis and Smith (1991) indicated the result supporting Lucas's theory that there was no trade-off between inflation and unemployment. In contrast, King and Watson (1994) examined the presence of Phillips curve using the US data. The finding provided empirical support for the presence of a trade-off relationship between unemployment and inflation in the United States during the research period. 
Islam et al. (2003) examined the presence of Phillips curve in the United States from 1950 to 1999. The result found that there was a long run cointegration and long run causality between unemployment and inflation. Hart (2003) examined the Phillips hypothesis in England using hourly wage over the period (1926-1966). The result did find any presence of Phillips curve in England during the period. Singh et al. (2011) analyzed the presence of Phillips curve in India. The research used inflation and output gap variables and the result provided evidence of the presence of Phillips curve in India in 2004 in the first quarter and in 2009 in the first quarter. Dritsaki (2012) also examined the presence of Phillips curve in Greece using NAIRU. The result found that there was a long run relationship between inflation and unemployment and the presence of Phillips curve in Greece.

This study differs from research conducted by other researchers related to the relationship of inflation and unemployment in the estimation of NAIRU data, but has the same method as Dritsaki (2012) using the VECM model. The difference in this study is that NAIRU data was obtained by researchers by estimating NAIRU's time varying from multiple linear regression with the BallMankiw (2002) approach. Ball-Mankiw (2002) assumed that expected inflation equals the previous year's inflation and extracts NAIRU using Hodrick Prescott Filters.

\section{THEORETICAL METHODOLOGY}

The research method with the analysis of short run supply function in Phillips curve in the recent research employs Lucas approach theory used by Dritsaki (2012). The derivation of aggregate supply equation can be seen in the equation (1) by Dritsaki (2012).

$$
\boldsymbol{p}=\boldsymbol{p}^{\boldsymbol{e}}+(\mathbf{1}+\boldsymbol{\alpha})\left(\boldsymbol{y}-\boldsymbol{y}^{*}\right)
$$

Where $\mathrm{p}$ is actual price, $\boldsymbol{p}^{e}$ is expected price, y is actual output, $\boldsymbol{y}^{*}$ is natural output and $\alpha$ is constant.Inflation expectation should be kept stable so as not to be high so that the economy does not experience a decrease.

In the initial step, add the right side of equation (1) with world supply shock (wss) to indicate exogenouse events (such as changes in world oil prices). The supply shock will change the price level and shift the short run aggregate supply curve, so the equation becomes:

$$
\boldsymbol{p}=\boldsymbol{p}^{e}+(\mathbf{1}+\boldsymbol{\alpha})\left(\boldsymbol{y}-\boldsymbol{y}^{*}\right)+\boldsymbol{w s s}
$$

To change the price level into inflation rate, it is conducted by reducing last year's price level p1 from both sides of equation (2),

so that it becomes:

$p-p(-1)=p^{e}-p^{e}(-1)+(1+\alpha)\left(y-y^{*}\right)+w s s$

The symbol on the left side, $p-p(-1)$ represents the difference between the curent price level and last year's price level, which is inflation (INFL). The symbol on the right side, $p^{\mathrm{e}}-\mathrm{p}^{\mathrm{e}}(-1)$ represents the difference between the expected price level and last year's price level, which is the expected inflation $\left(\mathrm{INFL}^{\mathrm{e}}\right)$, so equation 3 becomes:

$$
I N F L=I N F L^{\mathrm{e}}+(1+\alpha)\left(y-y^{*}\right)+w s S
$$

To shift from output to unemployment, it can include Okun's law providing a relationship between these two variables. Okun's law states that the output of the natural rate is inversely proportional to unemployment from the natural rate. If the output is higher from the natural rate of output, then unemployment is lower than the natural rate of unemployment. The equation can be written as follows:

$$
(\mathbf{1}+\boldsymbol{\alpha})\left(\boldsymbol{y}-\boldsymbol{y}^{*}\right)=-\boldsymbol{\beta}\left(\boldsymbol{u}-\boldsymbol{u}^{\boldsymbol{u}}\right)
$$


Where: $\mathrm{u}$ is unemployment rate, $\mathrm{u}^{\mathrm{u}}$ is natural rate of unemployment and $\beta$ is the constant. By using Okun's law relationship, $-\beta\left(u-u^{u}\right)$ can be substituted for $(1+\alpha)\left(y-y^{*}\right)$ in the previous equation to obtain:

$I N F L=I N F L^{*}-\beta\left(u-u^{u}\right)+w s S$

(6)

Equation 6 is a short run equation on Phillips curve indicating a negative slope between inflation rate (INFL) and unemployment rate (u).In this research, Phillips curve is modified by adding expected inflation, but expected inflation can not be observed directly, thus it is used adaptive expectation assumption so that $\pi^{\mathrm{e}} \mathrm{t}=\pi \mathrm{t}-1$ (Ball and Mankiw, 2002 andBarsky, 1987):

$$
\begin{aligned}
& \pi=\pi-1-\alpha\left(u-u^{\mathrm{u}}\right)+w s s \\
& \pi-\pi-1=\alpha u^{\mathrm{u}}-\alpha u+w s s \\
& \pi-\pi-1=c-\alpha u+w s s
\end{aligned}
$$

Equation (8) can be estimated with least square to obtain NAIRU estimate, so that in equation (8), it can be formed the following equation:

$$
\begin{aligned}
& (\pi-\pi-1)+\alpha u=\alpha u^{\mathrm{u}}+w s s \\
& \alpha u^{\mathrm{u}}+w s s=\alpha u+\Delta \pi \\
& u^{\mathrm{u}}+(v / \alpha)=u+\left(\begin{array}{ll}
\Delta / \alpha
\end{array}\right)
\end{aligned}
$$

From equation (11), it can be seen that the component $u^{u}$ is a smooth component estimated using HP filter from the component wt $=\mathrm{u}+(\Delta \pi / \alpha)$ because component $\mathrm{u}^{\mathrm{u}}$ varies, then it can be written to $\mathrm{u}^{\mathrm{u}}$ From constant $\alpha$, it is obtained slope at $\mathrm{ut}$ from regression $\left(\pi_{t}-\pi_{t-1}\right)$ on $\mathrm{u}_{t}$. Component $\mathrm{wt}$ is the total of NAIRU $\left(\mathrm{u}_{t}^{\mathrm{u}}\right)$ and supply shocks adjusted $\left(\mathrm{v}_{t} / \alpha\right)$. Component $\left(\mathrm{u}_{t}^{\mathrm{u}}\right)$ represents longer term trend and component $\left(\right.$ wss $\left._{t} / \alpha\right)$ represents shorter term supply shocks. To extract NAIRU $\left(\mathrm{u}_{t}^{\mathrm{u}}\right.$ ) from wt, the author used Hodrick-Prescott filter with $\lambda=100$. After obtaining NAIRU, then the equation can be written as follows:

$$
I N F L_{t}=\alpha(L) I N F L_{t-1}+\beta(L)\left(U N E M_{t}-N A I R U_{t}\right)+\varepsilon
$$

Where $\alpha(\mathrm{L})$ and $\beta(\mathrm{L})$ represent lag polynomial, UNEMt is a term for actual unemployment in year $t$ and NAIRUt is natural employment in year t. Equation (13) is modified to:

$$
I N F L=\alpha(L) I N F L_{t-1}+\beta(L) U N G A P+\varepsilon
$$

Where INFL is a term for inflation rate and UNGAP is a term for actual unemployment rate minus natural unemployment rate.

\section{DATASOURCE AND FRAMEWORK METHODOLOGY}

The recent study uses annual data in the period of 1991-2016. The data is obtained from World Bank. This research examines the effect of unemployment on inflation with Phillips curve approach performed with the following stages:

1. Unit Root Test with Augmented Dickey-Fuller (ADF) and Phillips-Perron (PP).

2. Cointegration test to find long run relationship between variables.

3. If the variables are cointegrated, then it is proceed with Granger causality test using Vector Error Correction Method (VECM) to find long run causality.

4. Wald test is carried out to determine short run causality relationship. 
In this line of study, data stationarity test is performed using Augmented Dickey-Fuller (ADF) and Phillips Perron (PP) on the same degree (level or difference) to obtain a stationary data, which is the data whose variant is not too large and having a tendency to approach the average value. Cointegration test in this research is used to determine whether there is a long run balance of variable in the model or not. This research uses Johansen test by comparing between the value of trace statistic andthe critical value at a confidence level of $10 \%, 5 \%$ and $1 \%$.

The data analysis model used in this research is quantitative by testing Vector Error Correction Model (VECM) which is a derivative of VAR. Prior to model testing, cointegration test is required by performing Johansen method. If the variables are not cointegrated and is stationary in the same order, then VAR can be applied. However, if the test proves that the variables are cointegrated, then VECM can be applied.

In predicting the effect of inflation and unemployment over the next several periods, Impulse Response Function (IRF) and Forecast Error Variance Decomposition (FEVD) are used. IRF is a method used to determine the response of an endogeneous variable to a particular shock. IRF can also measure the effect of a shock at a time to the innovation of endogeneous variable at that time and in the future. IRF aims to isolate a shock to be more specific, meaning that a variable can be affected by a certain shock. In FEVD, it can be seen the strengths and weaknesses of each variable in affecting other variable in a long period of time. FEVD characterizes forecast error variance into components that can be correlated with each endogenous variable in the model.

This study differs from research conducted by other researchers related to the relationship of inflation and unemployment in the estimation of NAIRU data, but has the same method as Dritsaki (2012) using the VECM model. The difference in this study is that NAIRU data was obtained by researchers by estimating NAIRU's time varying from multiple linear regression with the BallMankiw (2002) approach. Ball-Mankiw (2002) assumed that expected inflation equals the previous year's inflation and extracts NAIRU using Hodrick Prescott Filters.

\section{RESULTS}

In this research, unit root test is performed by using Augmented Dickey Fuller (ADF) popularized by Dickey and Fuller (1979) and Phillips-Perron (PP) by Phillips and Peron (1998). Both indicate the presence of unit root as the null hypothesis. Phillips-Perron uses non-parametric statistical method, so that it does not require lag in solving the problem of serial correlation (Breitung and Pesaran, 2005). The result of unit root test can be seen in Table 1.

Table 1. Result of Unit Root Test with ADF and PP

\begin{tabular}{|l|c|c|c|c|}
\hline \multirow{2}{*}{ Variable } & \multicolumn{2}{|c|}{ ADF } & \multicolumn{2}{c|}{ PP } \\
\cline { 2 - 5 } & At Level & 1 st Different & At Level & 1 st Different \\
\hline INFL & $-4.0914^{* * *}$ & $-5.8731^{* * *}$ & $-4.0602^{* * *}$ & $-14.89325^{* * *}$ \\
\hline UNGAP & -1.4723 & $-4.9786^{* * *}$ & -1.4624 & $-4.9786^{* * *}$ \\
\hline
\end{tabular}

Description: Based on the test result of ADF and PP. ${ }^{* * *},{ }^{* *}$ and ${ }^{*}$ indicate significance at level of 1 percent, 5 percent and 10 percent, respectively.

Based on Table 1, INFL variable is stationary at level either with ADF or PP, but UNGAP variable is non stationary at level, either with ADF or PP. This can be seen from the value of t-statistics greater than the critical value at level of 1 percent, 5 percent, and 10 percent, respectively. Therefore, since the data is non stationary at level of 0 percent, then data stationarity test is proceeded at the first difference.

Before performing an analysis with VECM, cointegration test is required. In cointegration test, Johansen lag used is the selected lag minus 1 because the variable is stationary at first difference. 
Table 2. Result of Johansen Cointegration Test

\begin{tabular}{|l|r|r|r|r|r|r|}
\hline Model & Hypothesized & Trace Statistic & Prob. & Max-Eigen Statistic & Prob & Variable \\
\hline \multirow{2}{*}{ Lag Length=3 } & None & 37.04 & 0.0000 & 25.36 & 0.0006 & INF \\
\cline { 2 - 7 } & At most 1 & 11.68 & 0.0006 & 11.68 & 0.0006 & UNGAP \\
\hline
\end{tabular}

Source: Result of Johansen Cointegration Test processed using Eviews (2018). *1\%

To figure out the causality relationship between the research variables, it can be performed by using Granger Causality test. The result of Granger Causality test can be seen in Table 3.

Table 3. Granger Causality Test

\begin{tabular}{|l|r|r|r|}
\hline Null Hypothesis: & Obs & F-Statistic & Prob . \\
\hline UNGAP does not Granger Cause INFLASI & 2 & 8.90284 & 0.0011 \\
\hline INFLASI does not Granger Cause UNGAP & & 9.74327 & 0.0007 \\
\hline
\end{tabular}

Source: Result of Granger Causality Test processed using Eviews (2018). *1\%

The result in Table 3 shows that inflation variable (INF) statistically has a significant effect on UNGAP value with the probability of 0.0011 or smaller than $\alpha=0.05$ while UNGAP statistically has a significant effect on inflation variable (INF) as evidenced by the probability value smaller than 0.05 , that is 0.0007 . After Johansen cointegration test is performed, then it is proceeded at the stage of VECM model. The use of VECM estimation is in accordance with problem formulation in this research, that is to identify long run relationship of the effect of independent variable on dependent variable.

Table 4. Result of Short RunVECM (Vector Error Correction Model) Estimate

\begin{tabular}{|l|c|rr|}
\hline Variable & Coefficient & \multicolumn{2}{|c|}{ T-statistic } \\
\hline DINFL(-1) & 1.000000 & Dependent \\
\hline DUNGAP(-1) & -3.5932 & {$[-3.0089]$} \\
\hline
\end{tabular}

Source: Test Result processed using Eviews 9 (2018).

Long run VECM estimate indicates that UNGAP variable has a negative and significant effect on inflation. It indicates if inflation rises then unemployment will fall. To analyze the short run causality relationship between independent variable to dependent variable, it can be performed with Wald Test. If the probability value of Chi-square $<0.05$, then there is short run causality relationship between variables. The lag coefficient of UNGAP is shown by C(6), C(7), C(8) and C(9). The result of Wald Test can be seen in the Table 5 .

Table 5. Estimation Result of Wald Test

\begin{tabular}{|l|r|r|r|}
\hline Test Statistic & Value & df & Probability \\
\hline f-statistic & 10.81238 & $(3,10)$ & 0.0018 \\
\hline Chi-square & 32.43714 & 3 & 0.0000 \\
\hline \multicolumn{2}{|c|}{ Null Hypothesis: $\mathrm{C}(6)=\mathrm{C}(7)=0$ and $\mathrm{C}(8)=\mathrm{C}(9)=0$} \\
\hline
\end{tabular}

Source: Test Result processed using Eviews (2018). 
Based on Wald Test in the Table 5, it can be seen the probability value of Chi-Square is 0.0000 or smaller than 0.05 . From the result, it can be concluded that there is a short run relationship between inflation variable and UNGAP variable in this research.
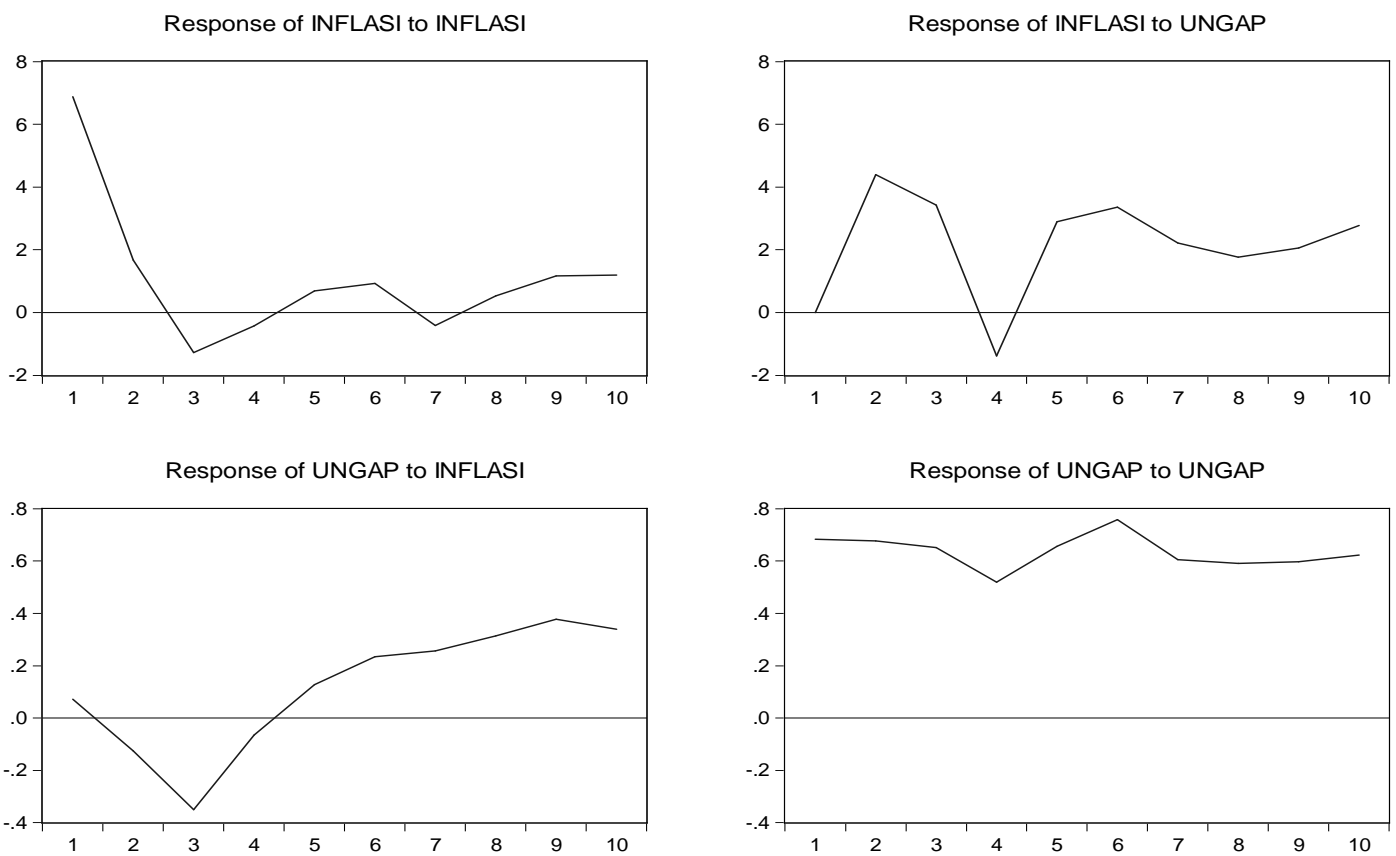

Figure 1. Impulse Response Function Source: Test result processed using Eviews (2018).

The response of inflation variable to UNGAP as can be seen in Figure 1 describes that if there is an increase of shock from UNGAP variable it will have an effect on inflation with fluctuating magnitude. Beginning with an increase in inflation in the 2 nd period, then creeps down in the 4 th period and then fluctuates back to the 10th period.

Table 6. Result of VDC Inflation Analysis

\begin{tabular}{|c|c|c|c|}
\hline \multicolumn{4}{|c|}{ Variance Decomposition of (INFL): } \\
\hline Period & S.E & INFL & UNGAP \\
\hline 1 & 6.871090 & 100.0000 & 0.000000 \\
\hline 2 & 8.325344 & 72.15293 & 27.84707 \\
\hline 3 & 9.090228 & 62.52320 & 37.47680 \\
\hline 4 & 9.205061 & 61.18396 & 38.81604 \\
\hline 5 & 9.673164 & 55.90552 & 44.09448 \\
\hline 6 & 10.28092 & 50.29660 & 49.70340 \\
\hline 7 & 10.52415 & 48.15083 & 51.84917 \\
\hline 8 & 10.68234 & 46.98074 & 53.01926 \\
\hline 9 & 10.94083 & 45.92024 & 54.07976 \\
\hline 10 & 11.34817 & 43.78633 & 56.21367 \\
\hline
\end{tabular}

Source: Data processed by Eviews 9 (2018)

The result of VDC analysis of the inflation variable shows that the variable that is expected to have the greatest contribution to inflation in the next ten years is inflation itself with an average 
contribution of 58.69 percent per year. This is in accordance with the theory of inflation expectations, where the rate of inflation that will come is influenced by the rate of inflation itself in the past.

Table 7. Result of VDC UNGAP Analysis

\begin{tabular}{|c|c|c|c|}
\hline \multicolumn{6}{|l|}{ Variance Decomposition of (UNGAP): } \\
\hline Period & S.E & INFL & UNGAP \\
\hline 1 & 0.687043 & 1.096442 & 98.90356 \\
\hline 2 & 0.972628 & 2.216098 & 90.35552 \\
\hline 3 & 1.221930 & 9.644483 & 91.61530 \\
\hline 4 & 1.329548 & 8.384698 & 92.56423 \\
\hline 5 & 1.488157 & 7.435771 & 92.29082 \\
\hline 6 & 1.686562 & 7.709181 & 91.30169 \\
\hline 7 & 1.809969 & 8.698308 & 89.70703 \\
\hline 8 & 1.929529 & 10.29297 & 87.54799 \\
\hline 9 & 2.055021 & 12.45201 & 86.44272 \\
\hline 10 & 2.173996 & 13.55728 & \\
\hline
\end{tabular}

Source: Data processed by Eviews 9 (2018).

The result of VDC analysis of the inflation variable shows that the variable that is expected to have the greatest contribution to UNGAP in the next ten years is UNGAP itself with an average annual contribution of 91.85 percent.

\section{CONCLUSION}

This paper was carried out to analyze the long run relationship between inflation and unemployment in NAIRU estimate in Indonesia and to determine the form of causality relationship among variables during 1991-2016 years period. The findings disclosed that Phillips curve theory could be applied in Indonesia from 1991 to 2016. The empirical obvious issue could be figured out from the results of regression model indicating that coefficient of inflation was negative and especially significant.

Based on the results of cointegration test using Granger causality test based on VECM, it indicated that there was long run causality relationship between unemployment rate and inflation rate. The findings of Granger Causality test demonstrated that inflation and unemployment showed a two-way relationship and statistically significant. The obvious phenomenon devoted that inflation prompted a significant effect on unemployment, and in turn, it has a significant effect on inflation. The result of this research suggested that UNGAP variable provided a negative and significant effect on inflation. Based on the result of Wald Test, short run relationship between inflation and unemployment was simply obtained. In the Forecasting Error Variance Decomposition analysis, inflation was the emerging variable with highest contribution to inflation.

This research provided an empirical evidence that there was a significantly negative relationship between inflation and unemployment in Indonesia. A country's economy might be stated as keen if at the some point, the inflation and unemployment rates are lower than the rate of economic growth achieved. The main purpose of macroeconomic policy, after all, is to overcome the inflation matters as the cause of price volatility and to solve terribly unemployment complication. By way of conclusion, macroeconomic policy shall be able to achieve its objectives, to create price stability and at the same time contribute to employment opportunities. 
In further research so that the determination of smoothing parameters in the Hodrick-Prescott filter uses criteria such as cross validation and generalized cross validation. Then because the BallMankiw approach assumes that expected inflation this year is the same as the previous year's inflation, so further research is expected not to use these assumptions but at the same time be estimated simultaneously with NAIRU using the Kalman filter or unobserved component method.

\section{REFERENCES}

Alogoskoufis, G. and Smith, R. (1991). "The Phillips Curve: The Persistence of Inflation and the Lucas Critique: Evidence from Exchange-Rate Regime." American Economic Review, 81, pp.1254-1275.

Ball, L.M., \& Mankiw, G.N. (2002). "The NAIRU in Theory and Practice." Journal of Economic Perspectives, 16, no. 4: 115-136.

Breitung, J. and Pesaran, M. (2005), “Unit roots and cointegration in panels”, Discussion Paper Series 1, Economic Studies No. 42, Deutsche Bundsbank, Frankfurt.

Dickey D.A. and Fuller W.A. (1979). "Distributions of the Estimators for Autore-gressive Time Series With a Unit Root." Journal of American Statistical Association, 74, 427- 431.

Dritsaki, Chaidodan Melina Dritsaki. (2012). "Inflation, Unemployment and Nairu in Greece." Procedia Economics and Finance, 118-127.

Friedman, M. (1968). "The Role of Monetary Policy." American Economic Review, 58, 1-17.

Helali, Kamel. (2018)." A New Assessment of the Non-Accelerating Inflation Rate of Unemployment and Capacity Utilization in Tunisia." The Romanian Economic Journal, 68, 54-77.

Heimberger, P., Kapeller, J. and Schutz, Bernhard. (2017). "The NAIRU determinants: What's structural about unemployment in Europe?" Journal of Policy Modeling, 39, 883-908.

Islam, F., Hassan, K., Mustafa, M. and Rahman, M. (2003). "The Empirics of U.S. Phillips Curve: A Revisit." American Business Review, 20(1), pp.107-112.

King, R.G. and Watson, M.W. (1994). "The Post-War U.S. Phillips Curve: A Revisionist Econometric History." Carnegie-Rochester Conference Series on Public Policy, 41, pp.157-219.

Lucas, R.E. (1976). "Econometric Policy Evaluation: A Critique." Carnegie-Rochester Conference Series on Public Policy, 1, pp.19-46.

Phelps, E. (1967). "Phillips Curve, Expectation of Inflation, and Optimal Inflation over Time."Economica, 34, 254-281.

Phillips, A.W. (1958). "The Relationship between Unemployment and the Rate of Change of Money Wage Rates in the United Kingdom.“ Economica, 25, pp.258-299.

Phillips, P.C., and Perron, P. (1988). "Testing for a Unit Root in Time Series Regression", Biometrika, 75, 335-346.

Samuelson, P.A. and Solow, R.M. (1960). "Analytical Aspect of Anti-inflation Policy." American Economic Review, 50, 177-194.

Singh, B. Karan, Kanakaraj, Sridevi, T.O. (2011). "Revisiting the empirical existence of the Phillips curve for India." Journal of Asian Economics, 22, 247-258.

\begin{tabular}{|l|l|}
\hline Article history: & Received: August 6, 2018 \\
\cline { 2 - 2 } & Accepted: November 30, 2018 \\
\hline
\end{tabular}

